\title{
Invertébrés Sans Frontières: Large Scales of Connectivity of Selected Freshwater Species among Caribbean Islands
}

\author{
Timothy J. Page ${ }^{1,6}$, Lucas S. Torati ${ }^{2}$, Benjamin D. Cook ${ }^{1,3}$, Andrew Binderup ${ }^{4}$, Catherine M. Pringle ${ }^{4}$, Silke Reuschel ${ }^{5}$, \\ Christoph D. Schubart ${ }^{5}$, and Jane M. Hughes ${ }^{1}$ \\ ${ }^{1}$ Australian Rivers Institute, Griffith University, Nathan, Queensland, 4111, Australia \\ ${ }^{2}$ EMBRAPA Fisheries and Aquaculture, 103 Sul. AV. J K ACSO 01, Conjunto 01, Lote $171^{\circ}$ piso. CEP 77015012, Palmas, TO, Brazil \\ ${ }^{3}$ frc environmental, PO Box 2363, Wellington Point, Queensland, 4160, Australia \\ ${ }^{4}$ Odum School of Ecology, University of Georgia, Athens, GA, 30602-2602, U.S.A.
}

${ }^{5}$ Biologie I, Universität Regensburg, Regensburg, Germany

\begin{abstract}
The freshwater fauna (crustaceans, molluscs, fish) of many tropical islands in the Caribbean and Pacific share an amphidromous lifecycle, meaning their larvae need to develop in saline conditions before returning to freshwater as juveniles. This community dominates the freshwaters of much of the tropics, but is poorly known and at risk from development, in particular dam construction. Amphidromy can theoretically lead to dispersal between different freshwater areas, even to distant oceanic islands, via the sea. The extent and scale of this presumed dispersal, however, is largely unknown in the Caribbean. Recent genetic work in Puerto Rico has shown that many freshwater species have little or no population structure among different river catchments, implying high levels of connectivity within an island, whereas between-island structure is unknown. We used genetic techniques to infer the geographic scales of population structure of amphidromous invertebrates (a gastropod and a number of crustacean species) between distant parts of the Caribbean, in particular Puerto Rico, Panama and Trinidad. We found virtually no geographic population structure across over $2000 \mathrm{~km}$ of open sea for these freshwater species. This implies that they are indeed moving between islands in sea currents as larvae, meaning that continued recruitment requires a continuum of healthy habitat from the freshwater to marine environment. We further discuss the role of amphidromy and suggest its ecological and biogeographic role may be more important than previously presumed.
\end{abstract}

Abstract in Spanish is available in the online version of this article.

Key words: amphidromy; Atya scabra; dispersal; Macrobrachium; Neritina virginea; Neotropics; phylogeography; Xiphocaris elongata.

THERE IS A CONSTANT TENSION BETWEEN THE TENDENCY OF ISOLATED POPULATIONS TO DIVERGE from each other or to remain similar. This process is evident in many systems, from the emergence of a new dialect in a colony distant from its home country, to different animal populations developing distinct forms. A key factor in determining whether a geographically separated dialect eventually becomes a new language, or a morphological variant diverges to a new species is the extent of connectivity between populations (Gillespie et al. 2012), which is a function of dispersal capacity and geographic distance. This in turn relies on the particular characteristics of the system, for example, is there easy transportation to the colonies, or can the creature in question easily disperse between populations? Here, the simple geographic distance between populations will also likely influence its place on a continuum of differentiation (identical language $\rightarrow$ dialect $\rightarrow$ different language; or identical species $\rightarrow$ distinct population $\rightarrow$ new species), however, determining the relevant geographic scale over which divergence might proceed is not, however, straightforward (Cowen et al. 2006).

Received 26 January 2012; revision accepted 14 April 2012.

${ }^{6}$ Corresponding author; e-mail: penguintim@hotmail.com
The islands of the Caribbean, with their complex geology and many examples of adaptive radiation (Ricklefs \& Bermingham 2008), have long provided inspiration in understanding the geography of biological relationships (Darlington 1938, Rosen 1976). In particular, the distributions of terrestrial vertebrates and birds have provided much of the evidence in the development of biogeographic theory (Ali 2012). The study of Caribbean freshwater animals, both fish and invertebrates, within the island-like nature of their aquatic habitats isolated by both salt water and land, have also contributed to biogeographic theory (Rosen 1976, Stock 1986).

The freshwater environments of many tropical islands, in both the Caribbean and Pacific, share certain physical characteristics, such as short, straight, steep river catchments (Covich 2006), with variable flows (Monti \& Legendre 2009). This has led to the development of a very particular pantropical freshwater island community of fish (Gobiidae and Eleotridae), decapod crustaceans (shrimps from the family Atyidae and palaemonid genus Macrobrachium) and molluscs (snails from the Neritidae) (McDowall 2004a). These share the specialized life history trait of amphidromy (March et al. 2003, Smith et al. 2003) where species spend most of their lives in freshwater, but reproduce in marine or estuarine environments (Bauer 2011). In general, females release 
many very small first-stage larvae in freshwater, which float passively to higher salinity habitats at the coast where they feed, grow and metamorphose through numerous planktonic larval stages over a number of months in the estuarine or marine environment (March et al. 1998, Blanco \& Scatena 2006), before returning to freshwaters as juveniles (Benstead et al. 2000, McDowall 2004a).

Certain life history strategies can have a significant effect on the scales of a species' population structure (Page \& Hughes 2007) and overall geographic distribution (Smith et al. 2003). An amphidromous reproductive cycle lends itself to a high level of connectivity between populations because a planktonic marine/ estuarine phase links up otherwise isolated aquatic habitats (Fièvet 1998). This is likely responsible for homogenizing freshwater communities on many tropical islands (Covich 2006). On the other hand, many different larval stages of amphidromous shrimps have been found within Caribbean estuaries, thus some amphidromous species may avoid the marine habitat and remain confined to estuaries where they complete development close to their adult freshwater habitat (Benstead et al. 2000). This strategy can maximize a safe return to freshwater habitats which can be scarce on many tropical islands (Crandall et al. 2010).

The alternative strategies of estuarine larval retention or marine dispersal suggest some hypotheses relevant to the geographic scales of species divergence, yet it is difficult to study the dispersal of widespread species directly (Rosen 1976). An indirect way to infer dispersal is to explore how genes have moved between populations (Cowie \& Holland 2006). Rosen (1976) showed that there is no point in looking between species to understand dispersal, as they are, by definition, genetically isolated. One must look at the geography and genetic relatedness of populations within a species (phylogeography) (McDowall 2004b). The nested nature of phylogeographic relationships makes the inference of connectivity possible, both historical and recent (Ricklefs \& Bermingham 2008).

A number of phylogeographic studies of amphidromous species from tropical Pacific islands has revealed a lack of geographic structure and considerable gene flow over scales from hundreds to thousands of kilometers of open ocean, as in neritid snails (Myers et al. 2000, Bebler \& Foltz 2004, Crandall et al. 2010), eleotrid and gobiid fish (Chubb et al. 1998), and atyid and palaemonid shrimps (Bebler \& Foltz 2004).

The amphidromous fauna of the Caribbean has also been investigated using genetic techniques, although these studies have generally been single-species studies limited to one island (e.g. Fièvet \& Eppe 2002). More general biogeographic conclusions require wider taxonomic sampling (Ebach 2011), as each species can serve as an independent replicate (Chubb et al. 1998). Many existing multiple-species studies have been phylogenetic in character, with only limited within-species phylogeographic data that could have a bearing on contemporary or historical levels of connectivity (Page et al. 2008). Some recent multi-species phylogeographic studies have included representatives from many tropical island taxa from isolated river drainages across the relatively large island of Puerto Rico (Cook et al. 2008a, 2009, 2010). Like many studies of amphidromous species, these found a more or less complete mixing of populations (panmixia) within nearly all species, implying that a high level of geneflow is occurring (Treml et al. 2008) via the marine environment. This means that the relevant geographic scales of genetic connectivity for these amphidromous species may be larger than the island of Puerto Rico itself.

Connectivity and population structure have important implications for the conservation of freshwater communities as, depending on the scale, natural recolonization may counteract localized extinctions (Monti \& Legendre 2009), which are common in highly variable tropical freshwater systems (Covich 2006). Migratory amphidromous species are a key component of the freshwater ecosystem of tropical islands, regulating many ecosystem processes (March \& Pringle 2003, Ramirez \& Hernandez-Cruz 2004). While this life history strategy affords some protection against perturbations because of a propensity for dispersal (McDowall 2010), amphidromous species can also be peculiarly vulnerable as they require near complete longitudinal connectivity (Benstead et al. 2000), with a reasonable quality environment required along nearly all of a river, from headwaters to estuary and the sea, to survive and breed (Snyder et al. 2011). Tropical freshwater ecosystems are becoming endangered with expanding human populations leading to habitat degradation and river fragmentation, lead by Puerto Rico (Moulton \& Wantzen 2006). The building of dams has largely denuded some upstream areas of migratory species in Puerto Rico (Greathouse et al. 2006), where 27 percent of stream kilometers are upstream of large dams (Snyder et al. 2011). Furthermore, in downstream areas of Guadeloupe, pollutants accumulate and thus contaminate the food web via juvenile fish and shrimps returning from the sea (Coat et al. 2011).

Migratory amphidromous species provide a link between headwaters, estuaries, and sea (Benstead et al. 2000). This dispersal has been studied in downstream (March et al. 1998), upstream (Kikkert et al. 2009), and in both directions (Crook et al. 2009), as well as between rivers within an island (Cook et al. 2009), but the marine component of migration between islands, which genetic data hint are important, is poorly known (Fièvet et al. 2001, Sorensen \& Hobson 2005). Presumably larvae are transported passively between islands by currents (Treml et al. 2008), which are complex and variable in the Caribbean (AlveraAzcarate et al. 2009), and may thus define metapopulation boundaries (Bilton et al. 2002). Cowen et al. (2006) used oceanic circulation models and biophysical larval data to split the Caribbean into four subregions, between which larval dispersal was said to be limited, and thus suggests a hypothesis for the interisland connectivity of amphidromous species.

Particular Caribbean islands have been the focus of much important ecological and molecular research on amphidromous taxa, such as Puerto Rico and Guadeloupe (Fièvet \& Eppe 2002, Cook et al. 2009), however, these studies and areas have not been effectively linked up to define the geographic scale at which relevant ecological and evolutionary processes appear to be operating (Nathan 2005). As the scales of marine dispersal can vary by five levels of magnitude (Nathan 2005), and depend on organismal traits (Gillespie et al. 2012), they are difficult to model without specific data (Treml et al. 2008). We aim to infer the geographic 
scales of population structure of Caribbean amphidromous invertebrates by incorporating specimens from across the region to discover if populations are panmictic across large areas, as is the case in the Pacific, or if there are distinct populations at the greaterthan-island scale, as is implied by some models (Cowen et al. 2006).

\section{METHODS}

STUDY SITES.-As numerous freshwater invertebrates from Puerto Rico had been sequenced in Cook et al. (2008a, 2009), we targeted the same species, but from other parts of the Caribbean so as to assess population differentiation across the region. In particular, we sampled the nearby Dominican Republic (approximately $120 \mathrm{~km}$ from Puerto Rico), as well as Jamaica and northern Trinidad (both roughly $1000 \mathrm{~km}$ from Puerto Rico), and the Bocas del Toro province of Panama (2000 km from Puerto Rico) (Fig. 1). In Panama, we sampled 20 sites on Isla Colón, Isla Bastimentos and the nearby mainland in western Panama (detailed in Torati et al. 2011). These included freshwater creeks, estuaries, and marine seagrass habitats that were not near the mouths of rivers.

STUDY SPECIES.-We collected adult shrimps, as well as juveniles and zoea larvae (sensu Williamson 1969) (Figs. S1 A and C). It is difficult to identify juveniles and zoeae to species accurately using traditional methods (Chace \& Hobbs 1969). This is because larval stages have fewer obvious characters, are dissimilar to adults of the same species, yet are very alike larvae of other related species, and so genetic techniques can help (Pardo et al. 2009). Shrimp specimens were captured with a seine, dip-net or baited box trap and were preserved in 95 percent ethanol.

Five invertebrate species were included in our study, all of which are known to be amphidromous (Chace \& Hobbs 1969, Blanco \& Scatena 2006). The atyid shrimp Atya scabra (Fig. S1) was sampled in Panama and Trinidad \& Tobago (as well as Puerto Rico; Table S1), but its distribution also encompasses coastal South America and West Africa. As an adult it is usually found in clear,

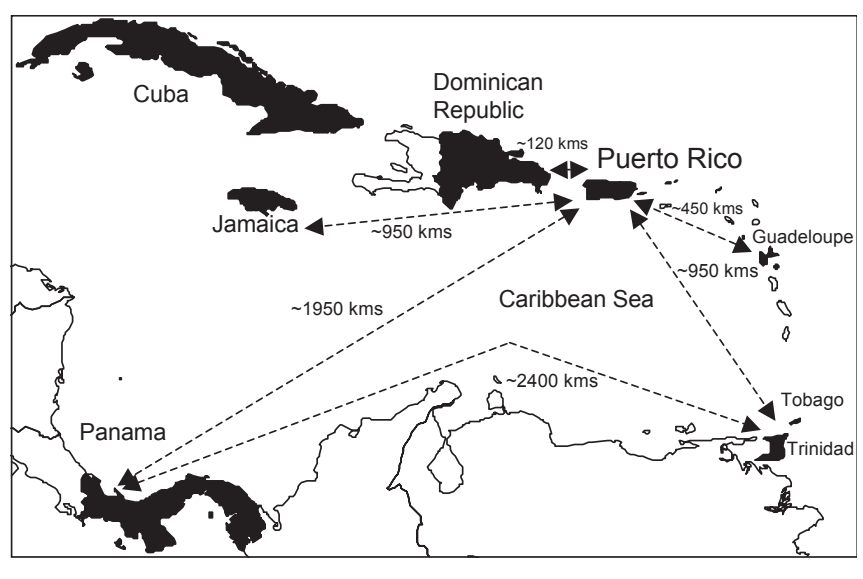

FIGURE 1. Islands of Caribbean and approximate distances between them. Areas in black are represented in our datasets. fast flowing streams, where it passively filter feeds using a special fan of hair-like setae (Fig. S1 D) (Hobbs \& Hart 1982). It has a relative high fecundity when compared with other atyids (Almeida et al. 2010) and ten planktotrophic larval stages (Fig. S1 C), before reaching the juvenile stage after 53 days (Fig. S1 A) (Abrunhosa \& Moura 1988). The shrimp Xiphocaris elongata, which is generally found in stream pools (Fryer 1977), was sampled in Jamaica, the Dominican Republic, Puerto Rico, Cuba and Guadeloupe. We were provided with specimens of the neritid snail Neritina virginea from Bocas del Toro, Panama, to compare with Puerto Rican specimens from Cook et al. (2009) (Table S2). This species is found in lowland streams usually within $10 \mathrm{~km}$ of the coast, often among boulders in riffles (Blanco \& Scatena 2006). The palaemonid shrimp Macrobrachium crenulatum was collected in Trinidad and compared with sequences from Guadeloupe (G. Zimmerman, A. Van Wormhoudt, G. Marquet, N. Ameziane, D. Defaye, P. Valade \& P. Keith, unpubl. data). Sequences of Macrobrachium faustinum from Guadeloupe from the same study were compared with Puerto Rican specimens from Cook et al. (2008a) (Table S2). Both Macrobrachium species are predators and scavengers, and are often found in quiet pools in island streams (Chace \& Hobbs 1969) or areas of low flow (Monti \& Legendre 2009).

LABORATORY TECHNIQUES.-A few pleopods or a small piece of muscle tissue was used for each adult or juvenile specimen. Whole individuals were used for unknown microscopic zoeae. DNA was extracted and a portion of the mitochondrial cytochrome oxidase subunit I (COI) gene amplified and sequenced for each specimen as per Cook et al. (2008a). We designed the following PCR (polymerase chain reaction) primers to achieve this: Atya scabra - AtyaPL (5'- CAG AGC TMG GAC AAC CAG GYA GAT - 3') and AtyaCR (5'- GCA GAT GTA AAG TAG GCT CG - 3'); Xiphocaris elongata - COL15 (5' - CCT GCT GGD GGW GGW GAC CC - 3') and COH19 (5'- TAT ATA AGC ATC GGG GTA ATC - 3'); Macrobrachium spp. - MsppLCO (5' - TCT CAA CAA ACC ATA AAG ACA TTG - 3') and MsppHCO (5' - TAA ACT TCD GGR TGR CCA AAR AAT CA - 3'). For Neritina virginea, we used the primers NVCOI-F (5'- GGA AAC TGA T'TG GTG CCT CTA ATG C -3'), and NVCOI-R (5' - ACC CCC TCC TGC TGG ATC - 3') (Cook et al. 2009).

GENETIC ANALYSES.-Each species was analyzed as a separate dataset. The phylogeographic relationships between the large number of $A$. scabra haplotypes were assessed by inferring a Minimum Evolution tree using PAUP* v. 4.0 b10 (Swofford 2002) with a K2P distance model. Haplotype networks were constructed for all of the other species using TCS v. 1.21 (Clement et al. 2000). For the three species with at least 10 specimens per area (Puerto Rico, Panama, Trinidad \& Tobago, Dominican Republic, Jamaica), namely A. scabra, N. virginea, and X. elongata, overall $\Phi_{\mathrm{ST}}$ and pairwise $\Phi_{\mathrm{ST}}$ 's were calculated between relevant areas to assess the amount of genetic variation explained by geography using Arlequin v. 3.5 (Schneider et al. 2000), with 1000 permutations for significance testing. Molecular diversity was also measured in these three species by calculating haplotype diversity 
(b), nucleotide diversity $(\pi)$ and mean pairwise nucleotide differences $(k)$ in Arlequin.

\section{RESULTS}

ATYA SCABRA.-All previously unidentified zoeae from freshwaters and juveniles from estuarine and marine environments that we sampled in Panama proved to be Atya scabra when their sequences were compared with those of identified adults and with other atyid species collected in the rivers (Torati et al. 2011). The new sequences from Panama and Trinidad and Tobago were aligned with published ones from Puerto Rico (from Cook et al. 2008a) into a dataset, 591 base pairs (bp) long (new GenBank accession numbers for all species JF810967-JF811004, JQ436643JQ436690; see Tables S1 and S2). As found by Cook et al. (2008a) in Puerto Rico, this species has proved to have very high genetic diversity in all measures, even within the smaller number of specimens from Panama and Trinidad \& Tobago (Table 1). This implies a very large effective population size (Ricklefs \& Bermingham 2008). Some haplotypes were shared between all three areas, and some just between Puerto Rico and Panama, or between Puerto Rico and Trinidad and Tobago (Fig. 2). There is no discernible geographic pattern of haplotypes, with the three areas spread liberally throughout the tree (Fig. 2). Overall $\Phi_{\mathrm{ST}}$ is very low $(<0.001)$ and is non-significant $(P=0.870)$. Pairwise $\Phi_{\text {ST }}$ between the different areas are all very low and non-significant (Panama vs. Puerto Rico $=0.001, P=0.316$; Panama vs. Trinidad and Tobago $=0.004, P=0.320$; Puerto Rico vs. Trinidad \& Tobago $\leq 0.001, P=0.861)$.

Neritina virginea. - The aligned dataset is $347 \mathrm{bp}$ (Table S2 for GenBank numbers). As with $A$. scabra above, $N$. virginea displays a high level of molecular diversity (Table 1). Also as in A. scabra, haplotypes are shared between the two areas represented (Panama and Puerto Rico) and there is no apparent phylogeographic structure (Fig. 3A). Pairwise $\Phi_{\mathrm{ST}}$ between Panama and Puerto Rico is $<0.001$ and non-significant $(P=0.818)$.
Xiphocaris elongata.-The aligned dataset is 620 bp (Table S2 for GenBank numbers). As for the two previous species, X. elongata displays a high level of molecular diversity (Table 1). Haplotypes are shared between Puerto Rico and Jamaica and between Puerto Rico and the Dominican Republic, with haplotypes from the different areas mixed (Fig. 3B). Overall $\Phi_{\mathrm{ST}}$ is low (0.042), but is significant $(P=0.005)$. Two of the three pairwise $\Phi_{\mathrm{ST}}$ 's between areas are low and non-significant (Puerto Rico vs. Jamaica $=0.001, \quad P=0.389 ; \quad$ Dominican Republic vs. Jamaica $=0.036, P=0.106$ ), but there is a shallow significant result between Puerto Rico and the Dominican Republic (0.077, $P=0.013)$.

Macrobrachium SPP.-The number of specimens from Guadeloupe was very low, and so diversity and full phylogeographic analyses are not really appropriate. The sequence of $M$. crenulatum (447 bp; Table S2) from Guadeloupe is nested within those from Trinidad (Fig. S2), and M. faustinum (653 bp; Table S2) shows a star pattern, with one of the Guadeloupe sequences shared with Puerto Rico and the other one base pair different (Fig. S2).

\section{DISCUSSION}

Phylogeography and Amphidromy.-The results of our interisland Caribbean study agrees with that of previous intra-island phylogeographic studies (e.g. Fièvet \& Eppe 2002, Cook et al. 2009), in that populations of amphidromous species are thoroughly mixed up into one large super-population and do not follow the marine phylogeographic boundaries proposed by Cowen et al. (2006). In an example of the exception proving the rule, Caribbean molecular studies of freshwater species that have identified withinisland geographic structure have generally been on species with direct development rather than amphidromous with multiple larval stages (crabs: Cook et al. 2008b, Schubart et al. 2011, fish: Walter et al. 2011). Cook et al. (2009) showed that the island-scale was insufficient to fully characterize the geographic extent of amphidromous connectivity, and our expanded scale has come to

TABLE 1. Molecular diversity indices ( \pm SE) for Atya scabra (Leach, 1815), Neritina virginea (Linnaeus, 1758), and Xiphocaris elongata (Guérin-Méneville, 1856) by region.

\begin{tabular}{|c|c|c|c|c|c|c|}
\hline \multirow[t]{3}{*}{ Atya scabra } & Panama & 19 & 16 & $0.965 \pm 0.036$ & $0.009 \pm 0.005$ & $5.146 \pm 2.608$ \\
\hline & Puerto Rico & 225 & 144 & $0.986 \pm 0.004$ & $0.010 \pm 0.007$ & $7.694 \pm 3.599$ \\
\hline & Overall & 256 & 160 & $0.987 \pm 0.003$ & $0.013 \pm 0.007$ & $7.471 \pm 3.502$ \\
\hline Neritina virginea & Panama & 10 & 8 & $0.956 \pm 0.059$ & $0.011 \pm 0.007$ & $3.844 \pm 2.109$ \\
\hline \multirow[t]{4}{*}{ Xiphocaris elongata } & Dominican Rep. & 12 & 12 & $1.000 \pm 0.034$ & $0.009 \pm 0.005$ & $5.833 \pm 3.000$ \\
\hline & Jamaica & 12 & 10 & $0.970 \pm 0.044$ & $0.006 \pm 0.004$ & $3.985 \pm 2.142$ \\
\hline & Puerto Rico & 22 & 19 & $0.987 \pm 0.018$ & $0.008 \pm 0.005$ & $5.087 \pm 2.565$ \\
\hline & Overall & 46 & 40 & $0.991 \pm 0.007$ & $0.008 \pm 0.005$ & $5.136 \pm 2.535$ \\
\hline
\end{tabular}




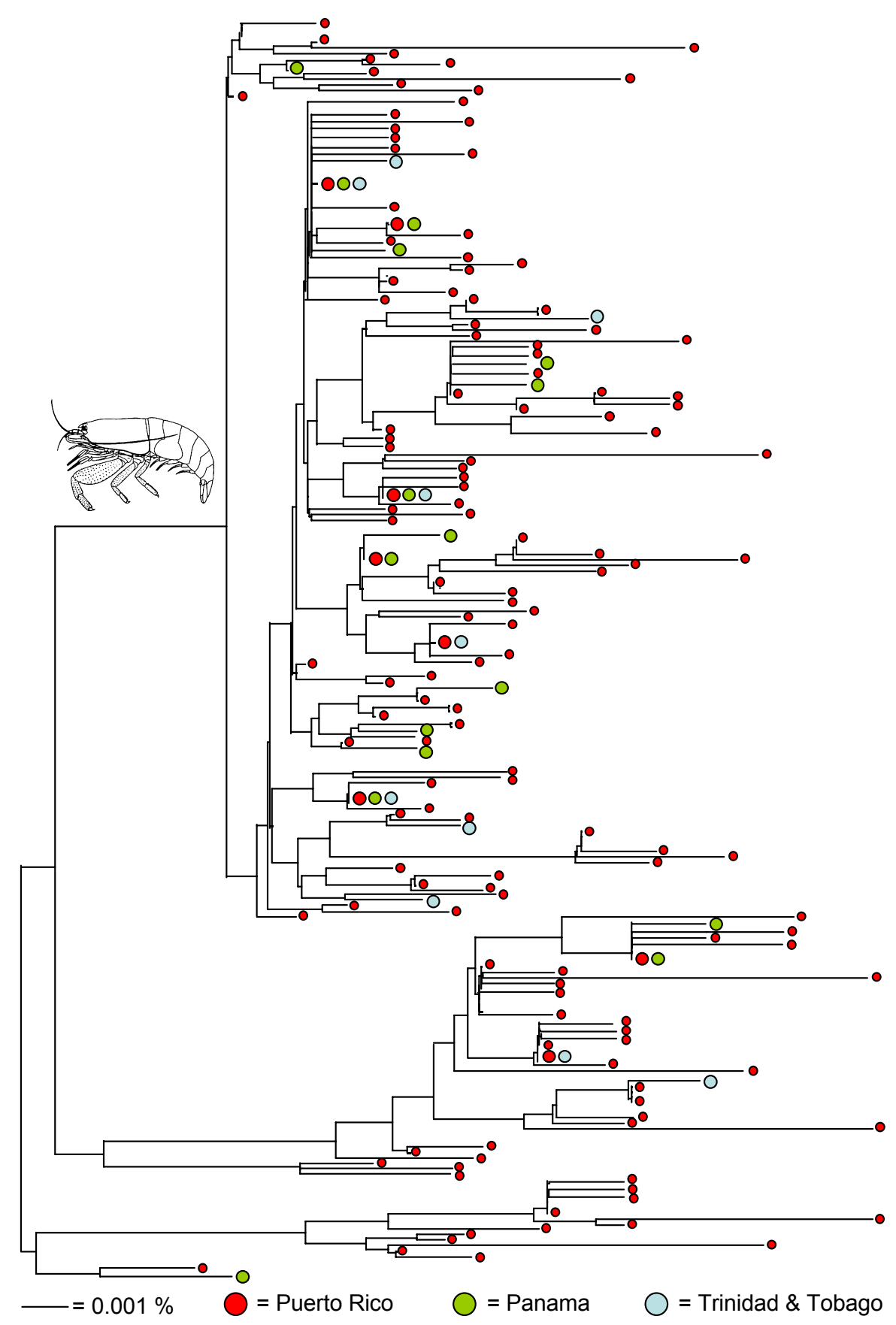

FIGURE 2. Atya scabra (Leach, 1815) Minimum evolution tree of sequences from Puerto Rico, Panama, and Trinidad \& Tobago (drawing from Fryer 1977, used with permission). Color version available online.

much the same conclusion. It may be that sampling will need to be undertaken even further afield to find the edge of metapopulation boundaries for these taxa, as Atya scabra is found as far away as West Africa (Hobbs \& Hart 1982). Crandall et al. (2010) found restricted geneflow in one species of neritid snail, but only at the very largest scale. For many species, however, our sampling covers the majority of their reported distributions (e.g., Xiphocaris). It may be simply that there are no strong local geographic patterns for many highly dispersive amphidromous species (Cook et al. 2012).
An alternative explanation is that the markers we used (mitochondrial DNA - mtDNA) are not fine-scale enough to detect geographic patterns (Bell 2009), as even a small amount of geneflow can homogenize the mtDNA of different populations (Cook et al. 2009). Populations can form smaller ecological units, which are functionally distinct and yet not easily detectable by molecular means (Bell 2009). However, when mtDNA and variable microsatellites have been used in conjunction on amphidromous taxa, they have often shown the same lack of 



$O=$ Puerto Rico $\quad$ = Panama $\quad$ = Dominican Rep. $\bigcirc=$ Jamaica
= cuba $\quad \bigcirc=$ Guadeloupe $\bullet=$ unsampled haplotype

FIGURE 3. Haplotype networks of (A) Neritina virginea (Linnaeus, 1758) (Neritidae) (photo by Paul Starosta from www.paulstarosta.com, used with permission); (B) Xiphocaris elongata (Guérin-Méneville, 1856) (Xiphocarididae) (drawing from Fryer 1977, used with permission). Color version available online.

geographic differentiation and high level of connectivity via dispersal (Schmidt et al. 2011).

The three main vectors of long distance dispersal of terrestrial and littoral organisms between islands are wind, birds, and ocean currents (Gillespie et al. 2012). While wind seems unlikely for these species, and bird mediated dispersal is certainly possible, particularly for snails (Wada et al. 2012), currents seem the most feasible method by which these aquatic species might disperse. Our data do not necessarily imply that individuals are moving thousands of kilometers through the Caribbean directly between Puerto Rico, Panama, and Trinidad, as there are many potential intermediate stepping stones, although only a limited number between the Greater Antilles (e.g., Puerto Rico) and Central America (Fig. 1). Nevertheless, our data show no evidence of restricted local estuary-to-estuary hopping, as this would eventually lead to genetic structure between regions, which was also absent in another amphidromous shrimp study (Dennenmoser et al. 2010).

'Freshwater' amphidromous species may be even more cosmopolitan than many marine species (Crandall et al. 2010), and form a single class of marine-based dispersers (Cook et al. 2010). While this may be true for the species in this study, the real situation may be more complex as there is some variation in geographic scales of connectivity, as Crandall et al. (2010) found for one species of snail, which was explained by a delay in larval metamorphosis. In another case, an amphidromous fish in Japan displayed population structure (Tsukagoshi et al. 2011), again due to a varying life history trait (different breeding times) combined with strong seasonal variation in ocean currents.

LARVAE AND OCEAN CURRENTS.-The scales of connectivity and resulting phylogeographic patterns are determined by a combination of both intrinsic biological factors (such as life history) and extrinsic physical factors (currents/hydrogeography) (Dawson 2012). Adults of many amphidromous species, such as snails (Myers et al. 2000) and atyid shrimps (Fryer 1977, Fièvet \& Eppe 2002), are surprisingly not very vagile (including those from the current study), and deal poorly with marine conditions. While species that have a high salinity tolerance as adults, but a life cycle of direct reproduction, can show much less marine dispersal (Walter et al. 2011). Active dispersers (swimming adults) often seem to travel less over their life time than passive ones (floating larvae) (Covich 2006), and so larval/juvenile stages appear to be the major agent of dispersal (Cowen et al. 2006, Treml et al. 2008).

The simple fact of an amphidromous life cycle may not determine scales of connectivity and population structure because life history variation within amphidromous species can be significant (as detailed above). In particular, the length of time larvae spend at sea (pelagic larval duration - PLD) is frequently identified as contributing to phylogeographic patterns, with longer durations leading to more connectivity and less population structure (Cowen et al. 2006). Ocean currents and relatively short or long PLDs have been invoked to explain geographic structure (Tsukagoshi et al. 2011) or its absence (Myers et al. 2000). Bell (2009) reminds us that although fish larvae are planktonic when young, they become nekton as they metamorphose and can swim against the currents of the Caribbean Sea, and thus neither PLD nor currents are strictly deterministic.

As life histories can vary, so do Caribbean surface currents (Alvera-Azcarate et al. 2009), both seasonally and over evolutionary time (Ali 2012), with the added complexity of extreme events (hurricanes) (Fièvet 1998). Life history traits set the stage, and currents provide the means, but a potential does not necessarily result in realized patterns (Slatkin's Paradox, see Dawson 2012). Specific scenarios integrating both biological and physical can be modeled and then tested with molecular methods (Treml et al. 2008) and compared with known biogeographic patterns, as done by Foster et al. (2012) for Caribbean coral populations.

Patterns of Caribbean freshwater Biogeography.-As in many fields, the early researchers of Caribbean biogeography laid out many of the broad issues, probable processes and ways to test hypotheses, even before the methods existed to do so. Darlington (1938) stressed the importance of ocean currents and the life cycles of animals, before either were well characterized. Rosen (1976) explained that really understanding dispersal required within-species data before genetics could be employed, and that 
Caribbean geological history, which is still being consistently revised (Ali 2012), could be highly influential. Darlington (1938) understood that current-mediated dispersal is not as haphazard as it would first appear, as the aquatic environment and its denizens follow regular cycles. Cowen et al. (2006) points out that persistent currents can produce general biogeographic patterns in the Caribbean, which can be then modeled (Treml et al. 2008). Once detailed information of physical and biological information are collected, marine dispersal becomes decidedly non-random (Cowie \& Holland 2006) and predictable (Gillespie et al. 2012). Rosen (1976) felt that dispersal was not a general pattern, but the data from our study and Cook et al. (2008a, 2009) imply that there is an important component of the Caribbean freshwater community that forms an ecological class, that results in a general biogeographic pattern from a common process (in this case amphidromy rather than plate tectonics).

AMPHIDROMY ON CONTINENTS.-Amphidromy is generally associated with tropical islands, such as the current study, where it can be the dominant life history trait (Covich 2006). There are, however, plenty of examples from continental areas (some temperate), from fish (McGlashan \& Hughes 2001, Crook et al. 2006, Schmidt et al. 2011, Thuesen et al. 2011), and shrimps (Walsh \& Mitchell 1995, Rome et al. 2009, Dennenmoser et al. 2010, Cook et al. 2012). These include many of the same taxa (e.g., gobiid and eleotrid fishes, atyid and palaemonid shrimps) and show a similar lack of genetic structure over large areas of coastline (e.g., McGlashan \& Hughes 2001, Dennenmoser et al. 2010). This should not be surprising as amphidromy is assumed to be an ancient trait within both fish (McDowall 2004a) and shrimp (Bauer 2011), and so its presence solely on tropical islands would seem unusual. McDowall (2010) provides some examples of amphidromy on continents, in particular in Central America, which also has short, steep catchments with variable flow, like those found on many tropical islands where amphidromous species flourish. Some long, slow flowing continental rivers, however, also host a few amphidromous species (such as Macrobracbium obione from the Mississippi River system; Bauer 2011). Recently, another continental example of an amphidromous-dominated ecosystem was identified in tropical Australia, with a community more like those of Pacific islands (Thuesen $e$ al. 2011). The ecological role of amphidromy is not as well understood as for some other life history strategies (Smith et al. 2003), perhaps because it is generally more prevalent in tropical areas (Moulton \& Wantzen 2006), and also perhaps because these species do not fit easily into either the freshwater or marine worlds (Bell 2009), but straddle them both and so fall between the research cracks. While the impact of amphidromy on freshwater biogeography may be poorly known, an increasing amount of data imply that it may not be merely a local oddity but rather plays a role at larger scales than currently appreciated.

\section{ACKNOWLEDGMENTS}

We thank Christopher Rogers (Kansas Biological Survey) and Melissa Frey (Royal British Columbia Museum) and the Leiden
Museum for giving us some specimens, Tobias Santl (Universität Regensburg) for help in the field, Arlene Wheatley (Griffith University) for help in the lab and Virgilio Hermoso (Griffith University) for improving our Spanish. This project began as part of the Shrimp Taxonomy Workshop hosted at the Smithsonian Tropical Research Institute's Bocas del Toro Research Station from August 4-16, 2008. We thank the students and organizers for all their help, namely Laura Anderson, Arthur Anker, Chris Ashelby, Rachel Collin, Nicole Dobson, Plinio Gondola, Sammy De Grave, Leslie Harris, Patricio Hernáez, Gabriel Jácome, Jure Jugovic, Juan Felipe Lazarus-Agudelo, Javier Luque, Betel Martínez-Guerrero, Nuno Simões, and Carolina Tavares. Sammy De Grave (Oxford University Museum) read and commented on an earlier version of this study. We dedicate this study to the memory of Bob McDowall, from New Zealand's National Institute of Water and Atmosphere, who was a passionate and pioneering researcher on the dispersal of freshwater fauna and the evolution of amphidromy.

\section{SUPPORTING INFORMATION}

Additional Supporting Information may be found in the online version of this article:

TABLE S1. Atya scabra specimen collection information: life stage, babitat collection site, coordinates and DNA sequence information.

TABLE S2. Collection site and DNA sequence information of Neritina virginea, Macrobrachium crenulatum, M. faustinum, and Xiphocaris elongata.

FIGURE S1. Atya scabra: (A) lateral view of juveniles; (B) lateral view of adults; (C) lateral view of minute zoea; and (D) detail of filtering cheliped fan of adult specimen.

FIGURE S2. Haplotype networks of (A) Macrobracbium crenulatum, and (B) Macrobracbium faustinum.

Please note: Wiley-Blackwell are not responsible for the content or functionality of any supporting materials supplied by the authors. Any queries (other than missing material) should be directed to the corresponding author for the article.

\section{LITERATURE CITED}

Abrunhosa, F., And M. G. Moura. 1988. O completo desenvolvimento larval do camarão Atya scabra (Leach) (Crustacea, Decapoda, Atyidae) cultivado em laboratório. Arquivo de Ciências do Mar, 27: 127-146.

Ali, J. R. 2012. Colonizing the Caribbean: Is the GAARlandia land-bridge hypothesis gaining a foothold? J. Biogeogr., 39: 431-433.

Almeida, A. O., E. C. Mossolin, And J. R. Luz. 2010. Reproductive biology of the freshwater shrimp Atya scabra (Leach, 1815) (Crustacea: Atyidae) in Ilheus, Bahia, Brazil. Zool. Stud., 49: 243-252.

Alvera-Azcarate, A., A. Barth, and R. H. Weisberg. 2009. The surface circulation of the Caribbean Sea and the Gulf of Mexico as inferred from Satellite altimetry. J. Phys. Oceanogr., 39: 640-657.

Bauer, R. T. 2011. Amphidromy and migrations of freshwater shrimps. I. Costs, benefits, evolutionary origins, and an unusual case of amphidromy. In A. Asakura (Ed.). New Frontiers in Crustacean Biology. Proceedings of the TCS Summer Meeting, Tokyo, 20-24 September 2009, pp. 145-156. Brill, Leiden, The Netherlands. 
Bebler, M. H., And D. W. Foltz. 2004. Genetic diversity in Hawaiian stream macroinvertebrates. Micronesica, 37: 119-128.

BELL, K. N. I. 2009. What comes down must go up: The migration cycle of juvenile-return anadromous taxa. Am. Fish. Soc. Symp., 69: 321-341.

Benstead, J. P., J. G. March, and C. M. Pringle. 2000. Estuarine larval development and upstream post-larval migration of freshwater shrimps in two tropical rivers of Puerto Rico. Biotropica, 32: 545-548.

Bilton, D. T., J. Paula, and J. D. D. Bishop. 2002. Dispersal, genetic differentiation and speciation in estuarine organisms. Estuar. Coast. Shelf Sci., 55: 937-952.

Blanco, J. F., and F. N. Scatena. 2006. Hierarchical contribution of riverocean connectivity, water chemistry, hydraulics, and substrate to the distribution of diadromous snails in Puerto Rican streams. J. North Am. Benthologic. Soc., 25: 82-98.

Chace, F. A., And H. H. Hobbs. 1969. The freshwater and terrestrial decapod crustaceans of the West Indies with special reference to Dominica. U.S. Nat. Mus. Bull., 292: 1-258.

Chubb, A. L., R. M. Zink, And J. M. Fitzsimons. 1998. Patterns of mtDNA variation in Hawaiian freshwater fishes: The phylogeographic consequences of amphidromy. J. Hered., 89: 8-16.

Clement, M., D. Posada, and K. A. Crandall. 2000. TCS: A computer program to estimate gene genealogies. Mol. Ecol., 9: 1657-1660.

Coat, S., D. Monti, P. Legendre, C. Bouchon, F. Massat, and G. Lepoint. 2011. Organochlorine pollution in tropical rivers (Guadeloupe): Role of ecological factors in food web bioaccumulation. Environ. Pollut., 159: 1692-1701.

Cook, B. D., S. Bernays, C. M. Pringle, and J. M. Hughes. 2009. Marine dispersal determines the genetic population structure of migratory stream fauna of Puerto Rico: Evidence for island-scale population recovery processes. J. North Am. Benthologic. Soc., 28: 709-718.

Cook, B. D., T. J. Page, and J. M. Hughes. 2012. Phylogeography of related diadromous species in continental and island settings, and a comparison of their potential and realized dispersal patterns. J. Biogeogr., 39: 421-430.

Cook, B. D., C. M. Pringle, and J. M. Hughes. 2008a. Molecular evidence for sequential colonization and taxon cycling in freshwater decapod shrimps on a Caribbean island. Mol. Ecol., 17: 1066-1075.

Cook, B. D., C. M. Pringle, and J. M. Hughes. 2008b. Phylogeography of an island endemic, the Puerto Rican freshwater crab (Epilobocera sinuatifrons). J. Hered., 99: 157-164.

Cook, B. D., C. M. Pringle, and J. M. Hughes. 2010. Immigration history of amphidromous species on a Greater Antillean island. J. Biogeogr., 37: 270-277.

Covich, A. P. 2006. Dispersal-limited biodiversity of tropical insular streams. Pol. J. Ecol., 54: 523-547.

Cowen, R. K., C. B. Paris, and A. Srinivasan. 2006. Scaling of connectivity in marine populations. Science, 311: 522-527.

Cowie, R. H., And B. S. Holland. 2006. Dispersal is fundamental to biogeography and the evolution of biodiversity on oceanic islands. J. Biogeogr., 33: 193-198.

Crandall, E. D., J. R. Taffel, and P. H. Barber. 2010. High gene flow due to pelagic larval dispersal among South Pacific archipelagos in two amphidromous gastropods (Neritomorpha: Neritidae). Heredity, 104: 563-572.

Crook, D. A., J. I. Macdonald, J. P. O'Connor, and B. Barry. 2006. Use of otolith chemistry to examine patterns of diadromy in the threatened Australian grayling Prototroctes maraena. J. Fish Biol., 69: 1330-1344.

Crook, K. E., C. M. Pringle, and M. C. Freeman. 2009. A method to assess longitudinal riverine connectivity in tropical streams dominated by migratory biota. Aquatic Conservation-Marine and Freshwater Ecosystems, 19: 714-723.

Darlington, P. J. 1938. The origin of the fauna of the Greater Antilles, with discussion of dispersal of animals over water and through the air. Q. Rev. Biol., 13: 274-300.

Dawson, M. N. 2012. Parallel phylogeographic structure in ecologically similar sympatric sister taxa. Mol. Ecol., 21: 987-1004.
Dennenmoser, S., M. Thiel, and C. D. Schubart. 2010. High genetic variability with no apparent geographic structuring in the mtDNA of the amphidromous river shrimp Cryphiops caementarius (Decapoda: Palaemonidae) in Northern-Central Chile. J. Crustac. Biol., 30: 762-766.

Евасн, M. C. 2011. Biogeógrafos del mundo... juníos!: un camino hacia la unificación. Revista de Geografía Norte Grande, 48: 5-10.

Fièvet, E. 1998. Distribution et capacités d'expansion des crevettes d'eau douce de la région caraibe: exemple des genres Macrobracbium et Atya (Crustacea: Caridea). Biogeographica, 74: 1-22.

Fièvet, E., S. DoléDec, And P. Lim. 2001. Distribution of migratory fishes and shrimps along multivariate gradients in tropical island streams. J. Fish Biol., 59: 390-402.

FiÈvet, E., AND R. Eppe. 2002. Genetic differentiation among populations of the amphidromous shrimp Atya innocous (Herbst) and obstacles to their upstream migration. Archiv für Hydrobiologie, 153: 287-300.

Foster, N. L., C. B. Paris, J. T. Kool, I. B. Baums, J. R. Stevens, J. A. San chez, C. Bastidas, C. Agudelo, P. Bush, O. Day, R. Ferrari, P. GonZalez, S. Gore, R. Guppy, M. A. McCartney, C. McCoy, J. Mendes, A. Srinivasan, S. Steiner, M. J. A. Vermeij, E. Weil, and P. J. Mumby. 2012. Connectivity of Caribbean coral populations: complementary insights from empirical and modelled gene flow. Mol. Ecol., 21: 1143-1157.

Fryer, G. 1977. Studies on the functional morphology and ecology of the atyid prawns of Dominica. Philos. Trans. R Soc. Lond. Ser. B Biol. Sci., 277: 57-129.

Gillespie, R. G., B. G. Baldwin, J. M. Waters, C. I. Fraser, R. Nikula, and G. K. Roderick. 2012. Long-distance dispersal: A framework for hypothesis testing. Trends Ecol. Evol., 27: 52-61.

Greathouse, E. A., C. M. Pringle, and J. G. Holmouist. 2006. Conservation and management of migratory fauna: Dams in tropical streams of Puerto Rico. Aquat. Conserv. Mar. Freshw. Ecosyst., 16: 695-712.

Hobbs, H. H., and C. W. Hart. 1982. The shrimp genus Atya (Decapoda: Atyidae). Smithson. Contrib. Zool., 364: 1-143.

Kikkert, D. A., T. A. Crowl, and A. P. Covich. 2009. Upstream migration of amphidromous shrimps in the Luquillo Experimental Forest, Puerto Rico: Temporal patterns and environmental cues. J. North Am. Benthologic. Soc., 28: 233-246.

March, J. G., J. P. Benstead, C. M. Pringle, and M. Luckymis. 2003. Benthic community structure and invertebrate drift in a Pacific island stream, Kosrae, Micronesia. Biotropica, 35: 125-130.

March, J. G., J. P. Benstead, C. M. Pringle, and F. N. Scatena. 1998. Migratory drift of larval freshwater shrimps in two tropical streams, Puerto Rico. Freshw. Biol., 40: 261-273.

March, J. G., and C. M. Pringle. 2003. Food web structure and basal resource utilization along a tropical island stream continuum, Puerto Rico. Biotropica, 35: 84-93.

McDowall, R. M. 2004a. Ancestry and amphidromy in island freshwater fish faunas. Fish Fish., 5: 75-85.

MCDowall, R. M. 2004b. What biogeography is: A place for process. J. Biogeogr., 31: 345-351.

MCDowall, R. M. 2010. Why be amphidromous: Expatrial dispersal and the place of source and sink population dynamics? Rev. Fish Biol. Fish., 20: $87-100$

McGlashan, D. J., and J. M. Hughes. 2001. Low levels of genetic differentiation among populations of the freshwater fish Hypseleotris compressa (Gobiidae: Eleotridinae): Implications for its biology, population connectivity and history. Heredity, 86(Part 2): 222-233.

Monti, D., And P. Legendre. 2009. Shifts between biotic and physical driving forces of species organization under natural disturbance regimes. Can. J. Fish. Aquat. Sci., 66: 1282-1293.

Moulton, T. P., And K. M. Wantzen. 2006. Conservation of tropical streams - Special questions or conventional paradigms? Aquat. Conserv. Mar. Freshw. Ecosyst., 16: 659-663.

Myers, M. J., C. P. Meyer, and V. H. Resh. 2000. Neritid and thiarid gastropods from French Polynesian streams: How reproduction (sexual, par- 
thenogenetic) and dispersal (active, passive) affect population structure. Freshw. Biol., 44: 535-545.

NATHAN, R. 2005. Long-distance dispersal research: Building a network of yellow brick roads. Divers. Distrib., 11: 125-130.

Page, T. J., B. D. Cook, T. von Rintelen, K. von Rintelen, and J. M. HugHEs. 2008. Evolutionary relationships of atyid shrimp imply both ancient Caribbean radiations and common marine dispersals. J. North Am. Benthologic. Soc., 27: 68-83.

Page, T. J., And J. M. Hughes. 2007. Radically different scales of phylogeographic structuring within cryptic species of freshwater shrimp (Atyidae: Caridina). Limnol. Oceanogr., 52: 1055-1066.

Pardo, L. M., D. Ampuero, and D. Veliz. 2009. Using morphological and molecular tools to identify megalopae larvae collected in the field: The case of sympatric Cancer crabs. J. Mar. Biol. Assoc. U. K., 89: 481-490.

Ramirez, A., And L. R. Hernandez-Cruz. 2004. Aquatic insect assemblages in shrimp-dominated tropical streams, Puerto Rico. Biotropica, 36: 259-266.

Ricklefs, R., and E. Bermingham. 2008. The West Indies as a laboratory of biogeography and evolution. Philos. Trans. R Soc. Lond. Ser. B Biol. Sci., 363: 2393-2413.

Rome, N. E., S. L. Conner, And R. T. Bauer. 2009. Delivery of hatching larvae to estuaries by an amphidromous river shrimp: Tests of hypotheses based on larval moulting and distribution. Freshw. Biol., 54: 1924-1932.

Rosen, D. E. 1976. A vicariance model of Caribbean biogeography. Syst. Zool., 24: 431-464.

Schmidt, D. J., D. A. Crook, J. P. O’Connor, and J. M. Hughes. 2011. Genetic analysis of threatened Australian grayling Prototroctes maraena suggests recruitment to coastal rivers from an unstructured marine larval source population. J. Fish Biol., 78: 98-111.

Schneider, S. D., D. Roessli, and L. Excoffier. 2000. Arlequin, Version 2.0: Software for population genetics and population analysis. Genetics and Biometry Laboratory, University of Geneva, Geneva.

Schubart, C. D., N. T. Rivera, K. A. Crandall, and T. Santl. 2011. Shallow phylogeographic structure of Puerto Rico freshwater crabs: An evolutionary explanation for low species diversity compared to Jamaica. In C. D. Schubart, C. Held, and S. Koenemann (Eds.). Phylogeography and Population Genetics in Crustacea, pp. 345-365. CRC Press, Boca Raton, FL.

Smith, G. C., A. P. Covich, And A. M. Brasher. 2003. An ecological perspective on the biodiversity of tropical island streams. Bioscience, 53: 1048 $-1051$.

Snyder, M. N., E. P. Anderson, And C. M. Pringle. 2011. A migratory shrimp's perspective on habitat fragmentation in the neotropics:
Extending our knowledge from Puerto Rico. In A. Asakura (Ed.). New Frontiers in Crustacean Biology. Proceedings of the TCS Summer Meeting, Tokyo, 20-24 September 2009, pp. 169-182. Brill, Leiden, The Netherlands.

Sorensen, P. W., And K. A. Hobson. 2005. Stable isotope analysis of amphidromous Hawaiian gobies suggests their larvae spend a substantial period of time in freshwater river plumes. Environ. Biol. Fishes, 74: 31-42.

Sтоск, J. H. 1986. Caribbean biogeography and a biological calendar for geological events. In R. H. Gore, and K. L. Heck (Eds.). Crustacean Biogeography: Crustacean Issues 3, pp. 195-203. A. A. Balkema, Rotterdam.

Swofford, D. L. 2002. PAUP * version 4.0b5-Phylogenetic Analysis Using Parsimony (* and other methods). Sinauer Associates, Sunderland, MA.

Thuesen, P. A., B. C. Ebner, H. Larson, P. Keith, R. M. Silcock, J. Prince, AND D. J. Russell. 2011. Amphidromy links a newly documented fish community of Continental Australian streams, to Oceanic Islands of the west Pacific. PLoS One, 6: e26685.

Torati, L. S., S. De Grave, T. J. Page, and A. Anker. 2011. Atyidae and Palaemonidae (Crustacea, Decapoda, Caridea) of Bocas del Toro, Panama. Check List, 7: 798-805.

Treml, E. A., P. N. Halpin, D. L. Urban, and L. F. Pratson. 2008. Modeling population connectivity by ocean currents, a graph-theoretic approach for marine conservation. Landscape Ecol, 23: 19-36.

Tsukagoshi, H., R. Yokoyama, and A. Goto. 2011. Mitochondrial DNA analysis reveals a unique population structure of the amphidromous sculpin Cottus pollux middle-egg type (Teleostei: Cottidae). Mol. Phylogenet. Evol., 60: 265-270.

WadA, S., K. Kawakami, And S. Chiba. 2012. Snails can survive passage through a bird's digestive system. J. Biogeogr., 39: 69-73.

Walsh, C. J., And B. D. Mitchell. 1995. The freshwater shrimp Paratya australiensis (Kemp, 1917) (Decapoda: Atyidae) in estuaries of south-western Victoria, Australia. Mar. Freshw. Res., 46: 959-965.

Walter, R. P., M. J. Blum, S. B. Snider, I. G. Paterson, P. Bentzen, B. A. Lamphere, And J. F. Gilliam. 2011. Isolation and differentiation of Rivulus hartii across Trinidad and neighboring islands. Mol. Ecol., 20: 601-618.

Williamson, D. I. 1969. Names of larvae in the Decapoda and Euphausiacea. Crustaceana, 16: 210-213. 